\title{
PRZYSTĄPIENIE UNII EUROPEJSKIEJ DO EUROPEJSKIEJ KONWENCJI O OCHRONIE PRAW CZŁOWIEKA I PODSTAWOWYCH WOLNOŚCI
}

\section{Uwagi wprowadzające ${ }^{1}$}

Przystąpienie Unii Europejskiej do Europejskiej konwencji o ochronie praw człowieka i podstawowych wolności ${ }^{2}$ stanowi obecnie najpoważniejsze wyzwanie polityczne oraz instytucjonalne dla całego sytemu ochrony praw człowieka w Europie. Można bowiem dziś mówić o istnieniu dwóch równoległych ponadnarodowych systemach ochrony praw człowieka, tj. o systemie ustanowionym przez prawo UE oraz o systemie ustanowionym przez konwencję. Systemy te były zawsze bardzo silnie ze sobą powiązane. Już w Jednolitym Akcie Europejskim³ z 1987 roku znalazło się odniesienie do konwencji, co później powtarzano w kolejnych traktatach ustanawiających i reformujących UE. Jednocześnie umacniał się system konwencji, co znalazło wyraz m.in. w orzecznictwie Europejskiego Trybunału Praw Człowieka (ETPC), nadającym zupełnie nowy wymiar prawom i wolnościom gwarantowanym w tekście konwencji ${ }^{4}$.

Proces przystąpienia stanowi wyzwanie dla obu tych systemów. Dla UE przede wszystkim w zakresie zagwarantowania autonomii prawa i systemu instytucjonalnego Unii, natomiast dla państw-stron konwencji z tego powodu, że po raz pierwszy do konwencji ma przystąpić niebędąca członkiem Rady Europy organizacja międzynarodowa ze swoim specyficznym systemem prawnym, a nie państwo ${ }^{5}$. Umowa o przystąpieniu UE do konwencji musi więc uwzględniać autonomię i specyfikę Unii jako organizacji międzynarodowej,

\footnotetext{
1 Niniejsze opracowanie oddaje stan prawny na dzień 1 stycznia 2013 roku.

2 Tekst konwencji zob. DzU 1993, nr 61, poz. 284 z późn. zm. Konwencja została otwarta do podpisu 4 listopada 1950 roku, a po uzyskaniu niezbędnych 10 ratyfikacji weszła w życie 3 września 1953 roku. 3 DzUrz. WE 1987 L 169/2.

${ }^{4}$ L. Garlicki, Przystąienie UE do Europejskiej Konwencji Praw Człowieka - przygotowania i problemy, „Europejski Przegląd Sądowy” 2011, nr 1, s. 14.

5 Zob. też J. Wołąsiewicz, Przystapienie Unii Europejskiej do Konwencji o ochronie praw człowieka i podstawowych wolności - wizja Rady Europy, w: Przystapienie Unii Europejskiej do Europejskiej Konwencji Praw Człowieka, „Biuletyn” 2010, nr 3-4, Biuro Informacji Rady Europy, Warszawa 2010, s. 23 i n.
} 
a jednocześnie gwarantować równość stron konwencji ${ }^{6}$. Kwestia przystąpienia UE do konwencji jest rezultatem dłuższego procesu ewolucji integracji europejskiej w kierunku poszerzenia jej na sferę polityczną. Jednym $z$ elementów tego procesu stało się włączanie problematyki ochrony praw jednostki do prawa UE, a jednym z podstawowych źródeł, do których sięgano przy budowie integracyjnej ochrony praw jednostki, była właśnie konwencja ${ }^{7}$.

Dyskusja nad przystąpieniem najpierw Wspólnoty Europejskiej, a potem UE do konwencji toczy się od ponad trzydziestu lat na forum instytucji wspólnotowych/ /unijnych i w ramach Rady Europy. Tło dla niej stanowi rosnąca rola UE we współczesnej Europie, zarówno pod względem ilościowym (obecnie 27 państw-stron konwencji należy do UE), jak i jakościowym (od czasów Traktatu o Unii Europejskiej z Maastricht ${ }^{8}$ Unia zaczęła obejmować swymi działaniami niemal wszystkie wymiary życia jednostki). Pozostawienie tej sfery poza kontrolą przestrzegania praw człowieka oznaczałoby stworzenie istotnego wyłomu w zakresie ochrony tych praw ${ }^{9}$.

Prace dotyczące przystąpienia WE/UE do konwencji obejmują inicjatywy instytucji wspólnotowych/unijnych oraz organów Rady Europy. Po stronie Rady Europy od dawna istniało przekonanie, że przystąpienie WE do konwencji znacząco wzmocni ochronę praw człowieka w Europie. W wielu zaleceniach i rezolucjach Zgromadzenia Parlamentarnego Rady Europy wskazywano na konieczność podjęcia negocjacji

${ }^{6}$ N. Półtorak, Przystąienie Unii Europejskiej do Konwencji o ochronie praw człowieka - projekt umowy akcesyjnej a prawo UE, „Europejski Przegląd Sądowy” 2012, nr 9, s. 7.

7 Zob. szeroko na temat ochrony praw podstawowych jednostki w UE m.in.: C. Mik, Przystapienie Unii Europejskiej do Europejskiej konwencji praw człowieka, w: Europejska konwencja praw człowieka i jej system kontrolny - perspektywa systemowa i orzecznicza, red. M. Balcerzak, T. Jasudowicz, J. Kapelańska-Pręgowska, Uniwersytet M. Kopernika, Torun 2011, s. 31 i n.; J. Van der Velde, The Protection of Fundamental Rights within the European Union - a historical approach, w: European Constitutionalism Beyond Lisbon, red. J. Wouters, L. Verhey, P. Kiiver, Intersentia, Antwerp 2009, s. 61 i n.; T.C. Hartley, The Foundations of European Union Law. An Introduction to the Constitutional and Administrative Law of the European Union, Oxford University Press, Oxford 2010, s. 141 i n.; A. Florczak, Ochrona praw podstawowych w Unii Europejskiej. Wybrane zagadnienia, Wydawnictwa Akademickie i Profesjonalne, Warszawa 2009, s. 11 i n.; A. Wyrozumska, Ochrona praw podstawowych w Unii Europejskiej - problemy pluralizmu porządków prawnych, w: Suwerenność i ponadnarodowość a integracja europejska, red. J. Kranz, Wydawnictwo Prawo i Praktyka Gospodarcza, Warszawa 2006, s. 148 i n.; A. Verstichel, European Union Accession to the European Convention on Human Rights, w: Protocol No. 14 and the Reform of the European Court of Human Rights, red. P. Lemmens, W. Vandenhole, Intersentia, Antwerp 2005, s. 125 i n.; F. van der Berghe, The EU and Issues of Human Rights Protection: Same Solutions to More Acute Problems?, „European Law Journal” 2010, Vol. 16, Nr 2, s. 113 i n.; M. Kuijer, The Accession of the European Union to the ECHR: A Gift for the ECHR'S 60th Anniversary or an Unwelcome Intruder at the Party, „Amsterdam Law Forum" 2011, Vol. 3-4, s. 18 i n.; J.R. Wetzel, Improving Fundamental Rights Protection in the European Union: Resolving Conflict and Confusion Between the Luxembourg and Strasbourg Courts, „Fordham Law Review" 2003, Vol. 7, Is. 6, s. 2823 i n.

8 DzUrz. WE 1992 C 191/1.

9 L. Garlicki, Komentarz do art. 59, w: Konwencja o Ochronie Praw Człowieka i Podstawowych Wolności. Komentarz do artykułów 19-59 oraz do Protokołów dodatkowych, t. II, red. L. Garlicki, C.H. Beck, Warszawa 2011, s. 456 i n. 
akcesyjnych ${ }^{10}$. W Zaleceniu 1017 (1985) wskazano, że wspólne przywiązanie do kwestii ochrony praw człowieka powinno wspierać się na jednolitych rozwiązaniach prawnych, których filarem jest konwencja ${ }^{11}$. W Rezolucji 1068 (1995) dotyczącej akcesji WE do konwencji zapisano, że istotą przystąpienia jest zbudowanie koherentnego systemu ochrony praw człowieka i unikanie ryzyka równoległej interpretacji przepisów przez Trybunał Sprawiedliwości UE (TS) oraz Europejski Trybunał Praw Człowieka (ETPC) ${ }^{12}$. W 2002 roku Komitet Sterujący ds. Praw Człowieka Rady Europy powołał grupę roboczą, która przedstawiła raport obejmujący prawne i techniczne kwestie związane $\mathrm{z}$ akcesją ${ }^{13}$. Raport ten przedstawia różne opcje związane z procesem przystąpienia UE do konwencji. Dokonano w nim także przeglądu tych przepisów konwencji, które wymagają nowelizacji, a także zastanawiano się m.in. nad udziałem przedstawiciela UE w postępowaniu sądowym oraz pozycji udziału sędziego unijnego w procedurze przed ETPC ${ }^{14}$.

W Unii Europejskiej dyskusja o jej ewentualnej akcesji do konwencji trwa w zasadzie od 1976 roku, gdy Komisja zwróciła uwagę na to zagadnienie Parlamentowi Europejskiemu (PE) i Radzie. Trzy lata później Komisja zdecydowała się sformułować w tej sprawie komunikat. Wobec braku akceptacji swoich propozycji przez Radę, Komisja powtórzyła ten komunikat w 1990 roku, a także w 1993 roku $^{15}$. Komisja uznała, że ochrona praw człowieka we WE jest niewystarczająca, ponieważ nie dotyczy aktów prawa wspólnotowego, a kontrola TS jest selektywna i jako faktycznie równoznaczna z kontrolą krajową uchybia idei zewnątrzkrajowej ochrony praw człowieka. Zdaniem Komisji przystąpienie WE do konwencji nie zwiększałoby obowiązków państw członkowskich w zakresie przestrzegania praw człowieka, gdyż są one już związane prawem materialnym i proceduralnym konwencji. Nowością

10 Zob. też H. Machińska, Przystąpienie UE do EKPCz. Relacje instytucjonalno-prawne Unii Europejskiej $i$ Rady Europy, w: Ochrona praw podstawowych w Unii Europejskiej, red. J. Barcz, C.H. Beck, Warszawa 2008, s. 250.

11 Zob. Parliamentary Assembly Council of Europe, Recommendation 1017 (1985) on the Future of European Co-operation: First Report of the Commission of Eminent European Personalities (Colombo Commission), pkt 15.

12 Zob. Parliamentary Assembly Council of Europe, Resolution 1068 (1995) on the Accession of the European Community to the European Convention on Human Rights, pkt 6.

${ }_{13}$ Zob. Study of Technical and Legal Issues of a Possible EC/UE Accession to the European Convention on Human Rights, CDDH(2002)010 Addendum 2.

14 Szerzej na ten temat zob. H. Machińska Umocnienie aksjologii przyszłej UE, w: Przyszły Traktat Konstytucyjny. Zagadnienia prawno-polityczne, instytucjonalne i proces decyzyjny w UE, red. J. Barcz, Wydawnictwo Prawo i Praktyka Gospodarcza, Warszawa 2004, s. 318 i n.

15 Zob. Commission Communication on Community accession to the European Convention for the Protection of Human Rights and Fundamental Freedoms and some of its Protocols, SEC (90) 2087 final, 19 November 1990. 
byłoby natomiast rozszerzenie kontroli procesowej na akty wspólnotowe. Koncepcja przystąpienia WE do konwencji nie zyskała wówczas jednak aprobaty Rady ${ }^{16}$.

Kwestia przystąpienia do konwencji powróciła po wejściu w życie Traktatu o Unii Europejskiej z Maastricht (1993 rok). Wówczas to Rada zdecydowała się wnieść do TS wniosek o wydanie opinii w sprawie ewentualnego przystąpienia WE do konwencji. Trybunał wydał opinię 28 marca 1996 roku $^{17}$. Stwierdził w niej, że w obowiązującym stanie prawnym przystąpienie WE do konwencji nie jest możliwe. TS uznał bowiem, że w dziedzinie ochrony praw człowieka WE nie ma kompetencji - ani wyraźnych, ani dorozumianych. Nie ma też kompetencji uzupełniających, gdyż ochrona praw człowieka nie stanowi celu traktatowego. Ponadto Trybunał wskazał, że przystąpienie spowodowałoby zasadniczą zmianę w obecnym systemie ochrony praw człowieka we WE. Wpisanie systemu wspólnotowego w system instytucjonalny konwencji oraz włączenie wszystkich jej postanowień do prawa wspólnotowego wykraczałoby poza kompetencje uzupełniające i wymagałoby rewizji traktatowej. Jednocześnie TS podkreślił, że przystąpienie WE do konwencji będzie możliwe dopiero po wprowadzeniu odpowiednich zmian do prawa pierwotnego.

Konsekwencją opinii Trybunału było umieszczenie odpowiedniego przepisu kompetencyjnego w traktatach. Nastąpiło to jednak dopiero w Traktacie z Lizbony ${ }^{18}$. Traktat ten przyniósł bowiem przełom $\mathrm{w}$ dwóch podstawowych dziedzinach, jeżeli chodzi o podniesienie spójności i efektywności unijnego systemu ochrony praw podstawowych jednostki ${ }^{19}$. Zasadnicze znaczenie mają $\mathrm{w}$ tym zakresie postanowienia art. 6 TUE $^{20}$. Po pierwsze, art. 6 TUE nadał Karcie Praw Podstawowych UE (KPP) ${ }^{21}$

16 C. Mik, op.cit., s. 35.

17 Zob. Opinia TS 2/94, Zb. Orz. 1996, s. I-1763.

18 Zob. Traktat z Lizbony zmieniający Traktat o Unii Europejskiej i Traktat ustanawiający Wspólnotę Europejską podpisany w Lizbonie 13 grudnia 2007 r., DzUrz. UE 2007 C 306/1. Traktat wszedł w życie 1 grudnia 2009 roku. Wersje skonsolidowane TUE i TFUE zob. DzUrz. UE 2010 C 81/1.

19 Zob. J. Barcz, Unia Europejska na rozstajach. Dynamika i główne kierunki reformy ustrojowej, wyd. 2, Instytut Wydawniczy EuroPrawo, Warszawa 2010, s. 117.

20 Artykuł 6 TUE stanowi:

„1. Unia uznaje prawa, wolności i zasady określone w Karcie praw podstawowych Unii Europejskiej z 7 grudnia 2000 roku, w brzmieniu dostosowanym 12 grudnia 2007 roku w Strasburgu, która ma taką samą moc prawną jak Traktaty.

Postanowienia Karty w żaden sposób nie rozszerzają kompetencji Unii określonych w Traktatach.

Prawa, wolności i zasady zawarte w Karcie są interpretowane zgodnie z postanowieniami ogólnymi określonymi w tytule VII Karty regulującymi jej interpretację i stosowanie oraz z należytym uwzględnieniem wyjaśnień, o których mowa w Karcie, które określają źródła tych postanowień.

2. Unia przystępuje do europejskiej Konwencji o ochronie praw człowieka i podstawowych wolności. Przystąpienie do Konwencji nie narusza kompetencji Unii określonych w Traktatach.

3. Prawa podstawowe, zagwarantowane w europejskiej Konwencji o ochronie praw człowieka i podstawowych wolności oraz wynikające z tradycji konstytucyjnych wspólnych Państwom Członkowskim, stanowią część prawa Unii jako zasady ogólne prawa”.

${ }^{21}$ KPP pierwotnie została uroczyście proklamowana w Nicei 7 grudnia 2000 roku wspólnie przez Radę, Komisję i Parlament Europejski oraz podpisana przez przedstawicieli tych instytucji. Początkowo 
charakter prawnie wiążący. Po drugie, ustanowił podstawę prawną umożliwiającą przystąpienie UE (już jako spójnej organizacji międzynarodowej) do konwencji22. Jednocześnie artykuł ten zobowiązał UE do przystąpienia, które jednak zostało obwarowane kilkoma warunkami proceduralnymi i materialnymi ${ }^{23}$. Oba te kroki wzajemnie się uzupełniają. Nie powinno się ich traktować alternatywnie, gdyż dopiero łączne ich spełnienie może skutkować osiągnięciem w Unii stopnia ochrony praw podstawowych jednostki porównywalnego do tego, jaki istnieje w państwach członkowskich UE, które chronią prawa podstawowe jednostki i jednocześnie zgodziły się na zewnętrzną kontrolę przestrzegania tych praw przez ETPC ${ }^{24}$.

\section{Podstawa prawna przystąpienia UE do Europejskiej konwencji o ochronie praw człowieka i podstawowych wartości}

Politycznym rozstrzygnięciem przyjętym zarówno w ramach Rady Europy, jak i UE była decyzja o potrzebie przystąpienia Unii do Europejskiej konwencji... Nie przewiduje się natomiast przystąpienia UE do Rady Europy, choć byłoby to możliwe w świetle art. 216 ust. 1 Traktatu o funkcjonowaniu Unii Europejskiej (TFUE), zgodnie z którym Unia może zawierać umowy także z innymi organizacjami międzynarodowymi.

Przystąpienie UE do konwencji wymagało wprowadzenia odpowiednich przepisów zarówno w traktatach unijnych, jak i w samej konwencji. Obydwie zmiany były ze sobą nierozerwalnie związane. W pierwszym przypadku chodziło nie tylko o stworzenie formalnych podstaw prawnych, ale także o przyznanie kompetencji UE do zawarcia traktatu w dziedzinie, w której generalnie Unia kompetencji do tej

nie miała jednak mocy prawnie wiążącej, pierwotną wersję KPP zob. DzUrz. WE C 364/1. Wejście w życie Traktatu z Lizbony spowodowało, że moc prawna KPP uległa zasadniczej zmianie. Z mocy art. 6 ust. 1 TUE KPP „ma taką sama moc prawną jak Traktaty”, czyli obecnie ma moc prawa pierwotnego. Pierwotna wersja KPP została poddana redakcji i Karta została ponownie uchwalona przez PE, Radę i Komisję 12 grudnia 2007 roku. Tekst zob. DzUrz. UE 2007 C 303/1. Ta wersja KPP została następnie zmieniona przez Protokół o sprostowaniu do Karty Praw Podstawowych Unii Europejskiej, podpisanej w Strasburgu dnia 12 grudnia 2007 r., DzUrz. UE 2010 C 81/9. Zob. tę wersję KPP DzUrz. UE 2010 C 83/389.

22 Zob. L.S. Rossi, How Fundamental are Fundamental Principles? Primacy and Fundamental Rights after Lisbon, „Yearbook of European Law” 2008, Vol. 27, s. 77 i n.

${ }^{23}$ Szerzej na ten temat w dalszej części opracowania.

24 Zob. też A. Gajda, Ochrona praw podstawowych jednostki w procesie harmonizacji prawa karnego procesowego w Unii Europejskiej, Oficyna Wydawnicza SGH, Warszawa 2011, s. 83. 
pory nie miała. $\mathrm{W}$ drugim przypadku wprowadzenie odpowiedniego przepisu do konwencji miało ją otworzyć na UE ${ }^{25}$.

W Traktacie z Lizbony wprowadzono podstawę prawną przystąpienia UE do konwencji. Stał się nim art. 6 ust. 2 TUE $^{26}$. Stanowi on wyraźnie: „Unia przystępuje do Europejskiej konwencji o ochronie praw człowieka i podstawowych wolności. Przystąpienie do konwencji nie narusza kompetencji Unii określonych w Traktatach".

Postanowienie to odgrywa podwójną rolę. Stanowi podstawę prawną przystąpienia oraz rozwiązanie w kwestii kompetencji UE w tej materii. Artykuł 6 ust. 2 TUE formułuje zatem obowiązek przystąpienia UE do konwencji. Nie ma jednak w tym artykule wzmianki, czy przystąpienie będzie możliwe w przypadku Euratomu, ani co do tego, czy obejmuje ono także protokoły dodatkowe. Przepis ten nie pozostawia jednak UE czy państwom członkowskim UE swobody przystąpienia, ale to przystąpienie przesądza ${ }^{27}$. Nie wolno więc samego przystąpienia uzależniać od woli państw czy UE ${ }^{28}$.

Do kwestii przystąpienia UE do konwencji odnosi się również Protokół (nr 8) dotyczący artykułu 6 ustęp 2 Traktatu o Unii Europejskiej w sprawie przystąpienia Unii do Europejskiej konwencji o ochronie praw człowieka i podstawowych wolności i Deklaracja nr 2 odnosząca się do artykułu 6 ust. 2 Traktatu o Unii Europejskiej (dołączona do Aktu końcowego Konferencji Międzyrządowej, która przyjęła Traktat z Lizbony). Protokół (nr 8) i Deklaracja nr 2 określają zasady i bardziej konkretne warunki przystąpienia UE do konwencji. Istotny jest także art. 218 TFUE, który dotyczy procedury zawierania przez Unię Europejską umów międzynarodowych.

Jednocześnie należy podkreślić, że art. 6 ust. 2 TUE, Protokół (nr 8) i Deklaracja nr 2 zawierają szereg ograniczeń precyzujących zakres przedmiotowy, w którym musi mieścić się umowa o przystąpieniu UE do konwencji ${ }^{29}$. Po pierwsze, chodzi o zastrzeżenie przestrzegania kompetencji UE. W artykule 6 ust. 2 w zdaniu drugim zastrzeżono, że „przystąpienie do Konwencji nie narusza kompetencji Unii określonych w Traktatach". Zastrzeżenie powyższe sprecyzowane zostało w zdaniu pierwszym art. 2 Protokołu (nr 8), stwierdzającym, że umowa o przystąpieniu Unii do konwencji „zagwarantuje, że przystąpienie nie ma wpływu na kompetencje Unii ani uprawnienia jej instytucji”. W ten sposób potwierdzono, że UE - zawiera-

\footnotetext{
25 C. Mik, op.cit., s. 47.

26 Zob. też G. Di Federico, Fundamental Rights in the EU: Legal Pluralism and Multi-Level Protection After the Lisbon Treaty, w: The EU Charter of Fundamental Rights: From Declaration to Binding Instrument, red. G. Di Federico, Springer, Dordrecht-New York 2011, s. 45 i n.

27 N. Półtorak, op.cit., s. 5.

28 L. Garlicki, Przystapienie UE... , op.cit., s. 15.

${ }_{29}$ J. Barcz, Traktat z Lizbony. Wybrane aspekty prawne działań implementacyjnych, Wydawnictwo Prawnicze LexisNexis, Warszawa 2012, s. 335-337.
} 
jąc umowę - musi kierować się zasadą kompetencji przyznanych (powierzonych), stosownie do której „[...] Unia działa wyłącznie w granicach kompetencji przyznanych jej przez Państwa Członkowskie w Traktatach do osiągnięcia określonych w nich celów. Wszelkie kompetencje nieprzyznane Unii w Traktatach należą do Państw Członkowskich" ${ }^{\text {"30. }}$

Po drugie, zastrzeżenie zagwarantowania szczególnych cech Unii i prawa unijnego. Jest to bez wątpienia najistotniejszy i najbardziej skomplikowany problem. Protokół (nr 8) podkreśla w art. 1, że umowa o przystąpieniu Unii do konwencji „musi odzwierciedlać konieczność zachowania szczególnych cech Unii i prawa Unii", co powinno znaleźć odbicie zwłaszcza w szczególnych warunkach udziału Unii w organach kontrolnych konwencji (lit. a) oraz zagwarantowaniu, aby skargi państw nieczłonkowskich i skargi indywidualne „były kierowane prawidłowo” przeciwko państwom członkowskich UE lub przeciwko Unii (lit. b). Na istotny aspekt tego problemu wskazuje także Deklaracja nr 2, odnosząca się do konieczności zagwarantowania odpowiedniej współpracy między sądami unijnymi a Europejskim Trybunałem Praw Człowieka. Podkreśla się w niej, że przystąpienie do konwencji „powinno nastąpić w taki sposób, aby można było zachować szczególny charakter porządku prawnego Unii”. Następnie wskazuje się na „istnienie regularnego dialogu” między TS a ETPC i na konieczność jego „wzmocnienia” po przystąpieniu Unii do konwencji.

Po trzecie, zastrzeżenie zagwarantowania „własnych” mechanizmów rozstrzygania sporów związanych z wykładnią traktatów względnie konwencji. Umowa będzie również musiała wyjaśnić znaczenie i stosunek między art. 344 TFUE i art. 55 Europejskiej konwencji... . Głównie chodzić będzie o postanowienia art. 344 TFUE, tym bardziej że art. 3 Protokołu (nr 8) wyraźnie zastrzega, iż postanowienia umowy o przystąpieniu Unii do konwencji nie mogą mieć wpływu na art. 344 TFUE $^{31}$. Jeśli natomiast chodzi o art. 55 Europejskiej konwencji..., to zakres problemu jest o tyle mniejszy, iż jego postanowienia wyraźnie odsyłają (przy analogicznej regulacji jak w art. 344 TFUE) do wyjątków w „porozumieniach szczególnych”, a takim będzie bez wątpienia umowa o przystąpieniu UE do konwencji32.

Z kolei podstawą prawną po stronie konwencji umożliwiającą przystąpienie UE do Europejskiej konwencji... wprowadzono w następstwie podpisania 13 maja 2004 roku w Strasburgu Protokołu nr 14 do konwencji, zmieniającego jej system

${ }_{30}$ Por. art. 5 ust. 2 TUE oraz art. 4 ust. 1 TUE. Zob. też F. Giorgi, The enforcement of the Charter of Fundamental Rights of the European Union as a challenge for the multi-level protection system, „Law Working Paper Series" 2009, Nr 2, s. 10.

${ }^{31}$ Artykuł 344 TFUE stanowi: „Państwa Członkowskie zobowiązują się nie poddawać sporów dotyczących wykładni lub stosowania Traktatów procedurze rozstrzygania innej niż w nich przewidziana”.

32 J. Barcz, Traktat z Lizbony..., op.cit., s. 337. 
kontrolny ${ }^{33}$. Protokół ten wszedł w życie 1 czerwca 2010 roku po ratyfikowaniu go przez wszystkie państwa-strony konwencji ${ }^{34}$.

Protokół nr 14 wprowadził zmiany m.in. w art. 59 Europejskiej konwencji..., dodając do niego ust. 2: „Unia Europejska może przystąpić do niniejszej Konwencji”. Wprowadzenie tego przepisu było konieczne, gdyż w poprzednim stanie prawnym stroną konwencji mogło stać się tylko państwo, będące zarazem członkiem Rady Europy. Postanowienie tego artykułu nie budzi jednak wątpliwości. Unia Europejska na jego podstawie w każdej chwili może przystąpić do konwencji.

W ten sposób droga do przystąpienia Unii Europejskiej do konwencji została otwarta. Niemniej przystąpienie UE do konwencji wymaga rozważania szeregu innych, fundamentalnych kwestii prawnych i instytucjonalnych w relacjach między systemem Rady Europy (Europejską konwencją...) a Unią ${ }^{35}$.

\section{Forma prawna przystąpienia UE do Europejskiej konwencji o ochronie praw człowieka i podstawowych wolności}

Postanowienia art. 6 ust. 2 TUE nie precyzują formy prawnej przystąpienia UE do konwencji. Forma ta sprecyzowana została natomiast w postanowieniach Protokołu (nr 8), który w art. 1 stwierdza jednoznacznie, że „przystąpienie”, o którym mowa w art. 6 ust. 2 TUE, odbywa się na podstawie „umowy dotyczącej przystąpienia Unii do Europejskiej konwencji o ochronie praw człowieka i podstawowych wolności [...]”. W pozostałych dwóch artykułach Protokół (nr 8) również jednoznacznie wskazuje na „umowę" jako formę prawną przystąpienia Unii do konwencji. Dotyczy to także postanowień art. 218 TFUE, który w ust. 6 lit. a) pkt (ii) oraz ust. 8 stanowi o „umowie dotyczącej przystąpienia Unii do Europejskiej konwencji o ochronie praw człowieka i podstawowych wolności”.

Formy prawnej przystąpienia UE do konwencji nie precyzuje natomiast - wprowadzony na podstawie Protokołu nr 14 - art. 59 ust. 2 Europejskiej konwencji...,

\footnotetext{
33 European Treaty Series Nr 194.

${ }^{34}$ Ostatnim państwem, które ratyfikowało Protokół (nr 8), była Rosja.

35 Do tych kwestii nawiążę w dalszej części opracowania. Zaliczyć tu można m.in. takie kwestie, jak: sposób obecności sędziego UE w składzie ETPC, uczestniczenie UE w Komitecie Ministrów RE, który m.in. monitoruje wykonywanie orzeczeń ETPC i w Zgromadzeniu Parlamentarnym RE, zakres skargi przeciwko UE do ETPC, przystąpienie UE do protokołów dodatkowych do konwencji, określenie, kiedy następuje wyczerpanie drogi wewnętrznej, która stanowi podstawową przesłankę jurysdykcji ETPC, techniczne dostosowanie tekstu konwencji do pojawienia się w niej UE, która nie jest państwem. Szeroko na ten temat zob. też H. Machińska, Przystąpienie UE..., op.cit., s. 247 i n.
} 
w którym stwierdza się jedynie, że „Unia Europejska może przystąpić do niniejszej Konwencji”. Postanowienia takie dopuszczałyby możliwość przystąpienia Unii do konwencji w trybie przewidzianym $\mathrm{w}$ art. 59 ust. 4 Europejskiej konwencji... , tj. poprzez „złożenie dokumentów ratyfikacyjnych” (przystąpienie). Jeśli dodamy do tego, że zawarcie umowy akcesyjnej pociąga za sobą skomplikowaną procedurę związania się taką umową przez wszystkie państwa-strony konwencji, to pokusa sięgnięcia do „uproszczonej” procedury przystąpienia była duża ${ }^{36}$.

Wybrano ostatecznie formułę „Umowy o przystąpieniu Unii Europejskiej do Konwencji o ochronie praw człowieka i podstawowych wolności”. Zadecydowały o tym przede wszystkim względy merytoryczne. Przystąpienie Unii do konwencji warunkowane jest koniecznością przeprowadzenia w postanowieniach konwencji szeregu istotnych zmian merytorycznych oraz dostosowań technicznych. Zawarcie między Unią a państwami stronami konwencji umowy akcesyjnej stwarza możliwość jednoczesnego wprowadzenia takich zmian do konwencji.

\section{Procedura zawarcia umowy dotyczącej przystąpienia UE do Europejskiej konwencji o ochronie praw człowieka i podstawowych wolności}

Artykuł 6 ust. 2 TUE i Protokół (nr 8) nie regulują trybu przystępowania UE do konwencji. Oznacza to, że w tej mierze stosuje się ogólną procedurę przystępowania UE do umów międzynarodowych zawartą $\mathrm{w}$ art. 218 TFUE.

Procedura ta jest specyficzna i skomplikowana. Decyzję o podjęciu negocjacji podejmuje Rada. Ona też jest właściwa do wydania instrukcji negocjacyjnych, a także później kompetentna do decydowania o podpisaniu i ostatecznym związaniu konwencją. Negocjatorem unijnym konwencji jest Komisja. To na jej wniosek Rada podejmuje większością kwalifikowaną głosów decyzję o podpisaniu umowy akcesyjnej, jak również o jej zawarciu. Przy tym, w pierwszym przypadku, decyzja Rady będzie musiała być poprzedzona zgodą Parlamentu Europejskiego (por. art. 218 ust. 6 lit. a/ii TFUE). Z kolei na zasadzie odstępstwa od art. 216 ust. 2 TFUE, zgodnie z którym umowa międzynarodowa zawarta przez UE wiąże instytucje i państwa członkowskie, decyzja taka, podejmowana przez Radę jednomyślnie, wymaga dodatkowego zatwierdzenia przez państwa członkowskie, zgodnie z ich wymogami

${ }^{36} \mathrm{Na}$ temat koncepcji formuły prawnej przystąpienia zob. J. Barcz, Traktat z Lizbony..., op.cit., s. 337 i n. oraz C. Mik, op.cit., s. 52. 
konstytucyjnymi. Dopiero wówczas wejdzie ona w życie (por. art. 218 ust. 8 TFUE). Jej wejście w życie jednocześnie nie przesądza o wejściu w życie traktatu akcesyjnego. Traktat akcesyjny, mając na uwadze jego instytucjonalno-proceduralne konsekwencje, jako czynność wielostronna wymagał będzie akceptacji przez wszystkie strony konwencji i Unię Europejską. Dopiero wówczas konwencja stanie się wiążąca dla instytucji i państw członkowskich ${ }^{37}$.

Kolejnym, już strasburskim etapem postępowania byłoby formalne zawarcie umowy pomiędzy UE a państwami-stronami konwencji, co wymagałoby przyjęcia (ratyfikacji) przez wszystkie 47 państw-stron umowy. Tego rodzaju wymogi zapewniają aktowi akcesu UE do konwencji maksymalną legitymację demokratyczną, ale też sprawiają, że wiązanie się umową akcesyjną przez jej strony będzie skomplikowanym procesem politycznym i prawnym zarówno na szczeblu międzynarodowym (unijnym i RE), jak i przede wszystkim na szczeblu krajowym ${ }^{38}$. Należy także mieć na uwadze, że wejście w życie umowy akcesyjnej może się znacząco opóźnić, gdy jedno albo więcej państw członkowskich, PE, Rada lub Komisja Europejska (KE) złoży wniosek o uzyskanie opinii TS w sprawie zgodności umowy akcesyjnej z traktatami trybie art. 218 ust. 11 TFUE. Skutkiem negatywnej opinii Trybunału byłby brak możliwości jej wejścia w życie lub konieczność zmiany traktatów.

\section{Wszczęcie i prowadzenie negocjacji w sprawie umowy akcesyjnej}

Przygotowanie do prowadzenia negocjacji nad umową akcesyjną następowało zarówno po stronie Unii Europejskiej, jak i Rady Europy ${ }^{39}$. Po stronie UE 4 czerwca 2010 roku Rada przyjęła decyzję upoważniającą KE do prowadzenia negocjacji w sprawie przystąpienia UE do konwencji i określającą wytyczne negocjacyjne. KE została wyznaczona negocjatorem UE, a specjalna Grupa Robocza Rady Europy ds. Praw Podstawowych, Praw Obywatelskich i Swobodnego Przepływu Osób (FREMP) została mianowana specjalnym komitetem, zgodnie $\mathrm{z}$ art. 218 ust. 4 TFUE.

37 C. Mik, ibidem, s. 51.

38 J. Barcz, Traktat z Lizbony..., op.cit., s. 347.

39 Zob. szeroko na temat początku prac nad umową akcesyjną R. Kowalska, Pierwszy etap prac Unii Europejskiej nad przystapieniem do Europejskiej Konwencji Praw Człowieka - wytyczne negocjacyjne na rokowania akcesyjne, w: Przystapienie Unii Europejskiej..., op.cit., s. 43 i n. 
Ustalono również, że w stosownych posiedzeniach będzie uczestniczyć przedstawiciel TS jako obserwator ${ }^{40}$.

Po stronie Rady Europy przygotowania do przystąpienia Unii do konwencji podjęto stosunkowo wcześnie. Tak jak już wcześniej wspomniano, w czerwcu 2002 roku Komitet Sterujący ds. Praw Człowieka przygotował raport na temat prawnych i technicznych aspektów akcesu ${ }^{41}$. W związku z zakończeniem procedury ratyfikacyjnej Protokołu nr 14 w styczniu 2010 roku i jego wejściem w życie 1 czerwca 2010 roku Komitet Ministrów Rady Europy upoważnił 26 maja 2010 roku Komitet Sterujący ds. Praw Człowieka do wypracowania wspólnie z przedstawicielami UE „instrumentu prawnego" ustalającego warunki przystąpienia Unii Europejskiej do konwencji ${ }^{42}$. Następnie ten komitet upoważnił do prowadzenia negocjacji z UE nieformalną grupę składającą się z 14 członków (po 7 z państw członkowskich UE i państw-stron konwencji nienależących do UE), tj. Komitet Sterujący ds. Praw Człowieka-UE (CDDH-UE).

Członkowie grupy CDDH-UE nie zostali upoważnieni do podejmowania jakichkolwiek wiążących decyzji czy zobowiązań. Uprawnienia decyzyjne posiada Komitet Sterujący ds. Praw Człowieka i nadzorujący jego prace Komitet Ministrów Rady Europy. Grupa ta odbyła łącznie (do końca czerwca 2011 roku) osiem tur negocjacyjnych z przedstawicielami $\mathrm{KE}^{43}$.

W czerwcu 2011 roku grupa CDDH-UE sfinalizowała projekt umowy o przystąpieniu UE do konwencji. Projekt został ogłoszony w lipcu $2011 \mathrm{roku}^{44}$. Na nadzwyczajnym posiedzeniu grupy w dniach 12-14 października 2011 roku, kiedy miało nastąpić ostateczne przyjęcie tekstu umowy akcesyjnej, kilka państw członkowskich UE zgłosiło zastrzeżenia do projektu i uznało, że potrzebuje więcej czasu na uzgodnienie stanowisk na poziomie UE. O zaistniałej sytuacji Komitet Sterujący ds. Praw Człowieka poinformował Komitet Ministrów Rady Europy, uznając jednocześnie, że wypełnił swoje zadania i oczekuje dalszych instrukcji. Niemniej podczas tego spotkania postanowiono przedłużyć ten termin na przedstawienie jednomyślnego stanowiska w sprawie projektu umowy akcesyjnej do końca 2011 roku $^{45}$.

40 Zob. dok. Rady 13739/10 FREMP 37, Brussels, 20 September 2010.

${ }^{41}$ Zob. CDDH(2002) 010 Addendum 2.

42 Zob. dok. CM/Del/Dec(2010) 1085 E/28 May 2010.

43 Pierwsza tura miała miejsce 6-7 lipca 2010 roku w Strasburgu, ostatnia, ósma, 20-24 czerwca 2011 roku.

44 Zob. Draft legal instrument on the accession of the European Union to the European Convention on Human Rights, CDDH-UE (2011) final version, Strasbourg, 19 July 2011.

${ }_{45}$ Zob. Steering Committee for Human Rights (CDDH), Report to the Committee of Ministers on the elaboration of legal instruments for the accession of the European Union to the European Convention on Human Rights, Strasbourg, 14 October 2011, CDDH(2011) 009, pkt 5. 
W międzyczasie wznowiono dyskusję na forum grupy FREMP, aby wypracować możliwe rozwiązania uwzględniające obawy państw członkowskich UE, które zgłosiły zastrzeżenia w sprawie projektu (głównie Wielkiej Brytanii i Francji) ${ }^{46}$. Z uwagi jednak na konieczność osiągnięcia wspólnego stanowiska UE przed kolejnymi dyskusjami z partnerami negocjacyjnymi Unii w Strasburgu wszelkie ewentualne zmiany projektu umowy o przystąpieniu będą musiały być negocjowane przez KE dopiero wtedy, gdy państwom członkowskim uda się dojść do porozumienia. KE zapowiedziała, że nie otworzy ponownie negocjacji w ramach RE do czasu, kiedy Rada nie uzgodni wszystkich poprawek do umowy akcesyjnej. Następnie kilka państw członkowskich UE zasugerowało, aby negocjator w Strasburgu przedłożył pewne propozycje dotyczące zmian projektu umowy. Negocjacje zostały zatem czasowo zawieszone w oczekiwaniu na wyniki dyskusji na forum FREMP dotyczące propozycji zmian ${ }^{47}$.

W następstwie dyskusji na forum Rady ds. Wymiaru Sprawiedliwości i Spraw Wewnętrznych w dniu 27 kwietnia 2012 roku $^{48}$ wznowiono negocjacje w Strasburgu. Uznano bowiem, że należy niezwłocznie ponownie rozpocząć negocjacje nad umową dotyczącą przystąpienia UE do konwencji i równolegle pracować nad regulacjami wewnętrznymi UE związanymi z przystąpieniem.

Dnia 13 czerwca 2012 roku Komitet Ministrów Rady Europy poinstruował Komitet Sterujący ds. Praw Człowieka, by kontynuował negocjacje z UE w grupie ad hoc 47+1 (państwa członkowskie Rady Europy i Unia Europejska) z myślą o finalizacji instrumentów prawnych określających warunki przystąpienia UE do konwencji ${ }^{49}$.

Do tej pory odbyły się trzy posiedzenia grupy ad hoc $47+1$ Komitetu Sterującego ds. Praw Człowieka: 21 czerwca, 17-19 września i 7-9 listopada 2012 roku. Kolejne posiedzenia są planowane na 21-23 stycznia i 3-5 kwietnia 2013 roku $^{50}$. Jednocze-

46 Kwestie podniesione przez delegacje dotyczą takich spraw, jak: zakres przystąpienia UE do konwencji, brak wpływu przystapienia do konwencji na kompetencje państw członkowskich; zakres stosowania mechanizmu współpozwania oraz korzystanie z prawa głosu przez Unię i jej państwa członkowskie na forum Komitetu Ministrów podczas nadzorowania wykonywania orzeczeń wydanych przeciwko Unii przez ETPC. Szerzej na ten temat w pkt. 6 niniejszej pracy. W szczególności wśród elementów, które FREMP przeanalizował podczas prezydencji cypryjskiej, znajdują się następujące kwestie: ustalenie listy kandydatów na stanowisko sędziego ETPC, reprezentacja Unii w postępowaniach przed tym ETPC, określanie stanowisk Unii, obowiązek Unii i państw członkowskich do starania się o udział w charakterze współpozwanych, uwarunkowania związane ze zrzeczeniem się jurysdykcji, wniesienie sprawy do wielkiej izby, ugody i oświadczenia jednostronne, interwencje stron trzecich i egzekwowanie wyroków.

47 W 2012 roku posiedzenia FREMP odbyły się: 23 lipca, 11 września, 8 października, 22-23 października, 15 listopada, 29-30 listopad i 10 grudnia.

48 Zob. Press Release, 3162nd Council Meeting, Justice and Home Affairs, 26-27 April 2012.

49 Zob. Steering Committee for Human Rights (CDDH), Report to the Committee of Ministers on the elaboration of legal instruments for the accession of the European Union to the European Convention on Human Rights, (CM/Del/Dec(2011)1126/4.1, CM(2011)149.

50 Zob. dok. Rady UE z 23 listopada 2012, nr 16573/12. 
śnie ustalono, że przedmiot dyskusji będzie obejmował cztery zasadnicze kwestie: zakres przystąpienia, mechanizm współpozwania, wcześniejsze zaangażowanie TS oraz wykonywanie prawa głosu przez państwa i UE w Komitecie Ministrów Rady Europy $^{51}$.

Negocjacje nie są więc zakończone. Wiele regulacji projektu umowy akcesyjnej wymaga analizy i rozważenia, tak aby projektowany system nie tylko był zgodny z wymogami prawa UE i systemu konwencyjnego, ale był także rzeczywiście skuteczny ${ }^{52}$. Przedmiotem dalszej analizy będzie projekt umowy akcesyjnej wypracowany na ósmym posiedzeniu grupy negocjacyjnej i ogłoszony w lipcu $2011 \mathrm{roku}^{53}$.

\section{Najważniejsze postanowienia projektu umowy akcesyjnej}

Projekt umowy akcesyjnej obejmuje preambułę i 12 artykułów ${ }^{54}$ oraz projekt sprawozdania wyjaśniającego ${ }^{55}$. Taka umowa ma wywołać skutki prawne dwojakiego rodzaju. Po pierwsze, UE stanie się stroną konwencji. Po drugie, na jej podstawie do postanowień konwencji zostaną wprowadzone zmiany niezbędne w związku z przystąpieniem UE do konwencji.

Umowa o przystąpieniu UE do konwencji zgodnie z art. 2 Protokołu (nr 8) ma gwarantować, że „żadne jej postanowienia nie mają wpływu na szczególną sytuację Państw Członkowskich w odniesieniu do Konwencji Europejskiej, w szczególności protokołów do niej, środków podjętych przez Państwa Członkowskie w drodze odstępstwa od Konwencji Europejskiej zgodnie z jej art. 15 i zastrzeżeń do Konwencji Europejskiej dokonanych przez Państwa Członkowskie zgodnie z jej art. 57”. Wynika zatem z tego, że umowa akcesyjna nie powinna mieć wpływu na

51 Zob. też F. Tulkens, EU Accession to the European Convention on Human Rights, European Court of Human Rights, European Judicial Training Network, Seminar on Human Rights for European Judicial Trainers, Strasbourg, 9 October 2012 [materiał w posiadaniu autorki].

52 N. Półtorak, op.cit., s. 4.

53 Zob. Draft legal instrument on the accession of the European Union to the European Convention on Human Rights, CDDH-UE(2011) 16, final version, 19.07.2011.

${ }^{54}$ Poszczególne postanowienia projektu umowy akcesyjnej określają: art. 1 - Zakres przystąpienia i zmiany w art. 59 Europejskiej konwencji... art. 2 - Zastrzeżenia do Konwencji i jej Protokołów; art. 3 Mechanizm współpozwania; art. 4 - Sprawy między stronami; art. 5 - Wykładnia art. 35 i 55 Europejskiej konwencji; art. 6 - Wybór sędziów; art. 7 - Udział Unii Europejskiej w Komitecie Ministrów Rady Europy; art. 8 - Wkład finansowy Unii Europejskiej w wydatkach dotyczących Konwencji; art. 9 Zobowiązanie do respektowania postanowień umów należących do systemu Europejskiej konwencji...; art. 10 - Podpisanie i wejście w życie umowy akcesyjnej; art. 11 - Zastrzeżenia; art. 12 - Notyfikacje.

55 Zob. Draft explanatory report to the Agreement on the Accession of the European Union to the Convention for the Protection of Human Rights and Fundamental Freedoms, CDDH-UE(2011) 16 fin. 
istniejący zakres związania się przez poszczególne państwa członkowskie UE konwencją. Istotne jest to, że umowa akcesyjna będzie wiązać nie tylko UE, lecz także jej państwa członkowskie. Dlatego państwo członkowskie UE nie może być wbrew swojej woli związane konwencją w wyniku członkostwa w Unii w zakresie większym, niż to wynika z jego statusu jako państwa-strony konwencji. W zasadzie więc UE może się związać na mocy umowy akcesyjnej jedynie tymi protokołami, których stroną są wszystkie państwa członkowskie UE. Ponadto umowa taka powinna ustanawiać "klauzulę elastyczności”, która w przypadku związania się danym protokołem przez wszystkie państwa członkowskie UE po przystąpieniu UE do konwencji umożliwiałaby Unii związanie się takim protokołem ${ }^{56}$.

Projekt umowy akcesyjnej przewiduje przystąpienie UE do konwencji oraz do dwóch jej protokołów - nr 1 i nr 6 (por. art. 1 ust. 1 projektu umowy akcesyjnej) $)^{57}$. Natomiast w art. 1 ust. 2 projektu umowy akcesyjnej wprowadzane są zmiany do art. 59 ust. 2 Europejskiej konwencji... Mają one m.in. umożliwić przystąpienie UE do dalszych protokołów, stwarzając do takiego przystąpienia stosowną podstawę prawną. To ograniczone przystąpienie do protokołów wynika z podejścia państw członkowskich UE, które w przystąpieniu do pozostałych protokołów widziały rozszerzenie kompetencji UE, gdyż protokoły te nie zostały ratyfikowane przez wszystkie 27 państw UE ${ }^{58}$. Dlatego UE może się związać na podstawie umowy akcesyjnej jedynie tymi protokołami, których stroną są wszystkie państwa członkowskie UE. Jednak istniejąca „klauzula elastyczności” powoduje, że w przypadku związania się danym protokołem przez wszystkie państwa członkowskie UE po akcesie UE do konwencji umożliwia Unii związanie się takim protokołem ${ }^{59}$.

Przystąpienie UE do konwencji wymaga także przyjęcia pewnych rozwiązań o charakterze proceduralnym. Na taką potrzebę wskazuje art. 1 Protokółu (nr 8), stwierdzając konieczność stworzenia mechanizmów pozwalających właściwie - pod względem podmiotowym - kierować skargi. Oczekiwanie to przewiduje projekt

${ }^{56}$ J. Barcz, Traktat z Lizbony... , op.cit., s. 340-341. Warto wskazać także na Rezolucję Parlamentu Europejskiego z dnia 19 maja 2010 r. w sprawie międzyinstytucjonalnych aspektów przystąpienia Unii Europejskiej do Europejskiej konwencji o ochronie praw człowieka i podstawowych wolności, DzUrz. UE 2011 C 161 E/72, w której PE uznał, że Unia powinna przystąpić do wszystkich protokołów dodatkowych, niezależnie od ich ratyfikacji przez państwa członkowskie UE.

57 Protokół nr 1 do Europejskiej konwencji... z 1952 roku wprowadza ochronę mienia (art. 1), prawo do edukacji (art. 2) oraz prawo do wolnych wyborów (art. 3). Natomiast Protokół nr 6 do Europejskiej konwencji... z 1983 roku znosi stosowanie kary śmierci w czasie pokoju (art. 1).

58 Zob. krytycznie na ten temat: J.P. Jacqué, The accession of the European Union to the European Convention on Human Rights and Fundamental Freedoms, „Common Market Law Review” 2011, Vol. 48, s. 995 i n.

59 C. Mik, op.cit., s. 60. 
umowy akcesyjnej, wprowadzając tzw. mechanizm współpozwania (co-respondent mechanism) do jej art. $3^{60}$.

Mechanizm współpozwania jest więc niezbędny, aby zapewnić prawidłowe kierowanie skarg państw członkowskich i skarg indywidualnych przeciwko Unii i/lub państwom członkowskim UE. Mechanizm ten zakłada, że we wszystkich sprawach, w których kompetencje (a tym samym odpowiedzialność) Unii oraz jednego lub więcej państw członkowskich przecinają się czy nakładają, pojawi się możliwość ich łącznego występowania po stronie pozwanej. Innymi słowy, w postępowaniu dotyczącym każdej skargi przez ETPC pojawi się możliwość wystąpienia jako współpozwanego każdego $\mathrm{z}$ tych podmiotów ${ }^{61}$.

Procedura ta ma być zastrzeżona tylko dla UE i jej państw członkowskich. Jej konstrukcja jest uzasadniona specyfiką systemu unijnego, w którego ramach akty są wydawane przez UE jako przyszłą stronę konwencji, a wykonywane przez jej państwa członkowskie, także będące stronami konwencji. Podmiotem współpozwanym ma być więc podmiot, który odpowiada za podstawę prawną działania, a nie za samo działanie ${ }^{62}$.

Projekt umowy akcesyjnej precyzyjnie określa szczegóły mechanizmu współpozwania, wskazując zarówno sytuacje, w których pozwane jest jedno lub więcej państw członkowskich UE, a współpozwanym będzie UE (por. art. 3 ust. 2 projektu umowy akcesyjnej), jak i sytuacje, w której pozwana jest Unia, a współpozwanym będzie jedno lub więcej państw członkowskich UE (por. art. 3 ust. 3 projektu umowy akcesyjnej). Mechanizm ten może mieć zastosowanie również do sytuacji (por. art. 4 projektu umowy akcesyjnej), w której początkowo skarga skierowana jest jednocześnie do Unii Europejskiej i do jej państw członkowskich. Status jednego z pozwanych może się zmienić na współpozwanego, o ile w stosunku do niego spełnione są szczegółowe kryteria (testy) „uruchamiające” mechanizm współpozwania, zwłaszcza jeżeli jedna ze stron dopuściła się działania lub zaniechania w stosunku do skarżącego, druga natomiast ustanowiła podstawę prawną dla takiego działania ${ }^{63}$.

Szczególnie kontrowersyjnym problemem było określenie testów, które uruchamiają mechanizm współpozwania (por. art. 3 ust. 2 i 3 projektu umowy akcesyjnej).

60 Idea takiego mechanizmu pojawiła się już w raporcie Komitetu Sterującego ds. Praw Człowieka Rady Europy z 2002 roku. Zob. też T. Lock, Walking on a Tightrope: the Draft ECHR Accession Agreement and the Autonomy of the EU Legal Order, „Common Market Law Review” 2011, Vol. 48, s. 1039-1040.

${ }^{61}$ L. Garlicki, Przystapienie UE... , op.cit., s. 18. Zob. też N. O’Meara, „A More secure Europe of Rights?” The European Court of Human Rights, the Court of Justice of the European Union and EU Accession to the $E C H R$, „German Law Journal” 2011, Vol. 12, Nr 10, s. 1820 i n.

62 N. Półtorak, op.cit., s. 8. Zob. też X. Groussot, T. Lock, L. Pech, EU Accession to the European Convention on Human Rights: A Legal Assessment of the Draft Accession Agreement of 14th October 2011, „European Issues” 2011, Nr 218, s. 10-14.

${ }^{63}$ J. Barcz, Traktat $z$ Lizbony..., op.cit., s. 355. 
I tak jeżeli skarga jest skierowana przeciwko jednemu lub większej liczbie państw członkowskich UE (art. 3 ust. 2 Umowy akcesyjnej), test uważa się za spełniony (tj. Unia Europejska może uzyskać statusu współpozwanego), gdy okaże się, iż skarga pociąga za sobą pytanie o zgodność ze standardami konwencji postanowień prawa pierwotnego lub pochodnego Unii Europejskiej. Dotyczy to zwłaszcza sytuacji, kiedy możliwe byłoby uniknięcie naruszenia wyłącznie w wyniku nieposzanowania zobowiązań wynikających z prawa UE, tj. gdy prawo unijne nie pozostawia państwu członkowskiemu swobody w zakresie wydawanych krajowych środków implementacyjnych. Natomiast w przypadku, jeżeli skarga jest skierowana przeciwko UE (art. 3 ust. 3 Umowy akcesyjnej), jej państwa członkowskie mogą stać się współpozwanymi w postępowaniu, kiedy okaże się, że skarga pociąga za sobą pytanie o zgodność ze standardami konwencji prawa pierwotnego UE, zwłaszcza gdy możliwe byłoby uniknięcie naruszenia wyłącznie w wyniku nieposzanowania zobowiązań wynikających $z$ tego prawa ${ }^{64}$.

O nadaniu statusu współpozwanego decyduje ETPC jedynie na żądanie UE, względnie jej państw członkowskich (por. art. 3 ust. 5 projektu umowy akcesyjnej). Wniosek w sprawie nadania statusu współpozwanego musi być uzasadniony. Współpozwany będzie miał status strony i będzie związany jako strona rozstrzygnięciem ETPC. Tym samym zasadniczo różni się instytucja współpozwanego od interwencji strony trzeciej przewidzianej w art. 36 Europejskiej konwencji... , która daje możliwość złożenia pisemnych uwag i uczestnictwa w rozprawie, ale nie czyni z interwenienta strony ani nie zobowiązuje go do wykonania wyroku ${ }^{65}$.

Zaproponowany w projekcie umowy akcesyjnej mechanizm współpozwania ma zatem wyeliminować sytuacje, w których pozwane państwo członkowskie UE musiałoby ponosić odpowiedzialność za działanie lub zaniechanie wynikające $\mathrm{z}$ jego obowiązków względem UE, bądź też Unia musiałaby odpowiadać za naruszenie spowodowane przez państwo członkowskie UE. Jego celem jest także ochrona skarżących, których skargi mogłyby być odrzucone z powodu mylnego wskazania sprawcy naruszenia. Nierealne byłoby bowiem oczekiwać od obywateli szczegółowej znajomości prawa unijnego czy wiedzy, które $\mathrm{z}$ dziedzin działalności publicznej leżą $\mathrm{w}$ sferze wyłącznej kompetencji państw członkowskich, a które wynikają z aktywności UE.

$\mathrm{Z}$ mechanizmem współpozwania związana jest jeszcze jedna innowacyjna procedura mająca za zadanie zagwarantowanie UE wyłącznej możliwości oceny własnego prawa, a tym samym usankcjonowania jej autonomii. Elementem tej autonomii jest

\footnotetext{
${ }^{64}$ Ibidem, s. 356-357.

65 N. Półtorak, op.cit., s. 8; J. Barcz, Traktat z Lizbony..., op.cit., s. 355. Zob. też J.P. Jacqué, The Accession of the European Union to the European Convention on Human Rights and Fundamental Freedoms, „Common Market Law Review” 2001, Vol. 48, s. 1014 i n.
} 
kontrola prawa UE przez TS, w tym interpretacja prawa unijnego, której przyznanie sądowi międzynarodowemu było dotychczas traktowane przez TS jako naruszenie zasady autonomii systemu UE, a więc naruszenie traktatów ${ }^{66}$. Chodzi mianowicie o możliwość uprzedniego (wcześniejszego) zaangażowania Trybunału w przypadkach, w których nie miał on możliwości orzekania w sprawie zgodności z prawami podstawowymi przepisu prawa UE istotnego dla postępowania przed ETPC.

Do tej kwestii odniósł się sam Trybunał w Dokumencie roboczym z maja 2010 r. $^{67}$ Trybunał zauważył, że stosownie do zasady subsydiarności kontrola zewnętrzna działań Unii (ze strony ETPC) powinna być poprzedzona skuteczną kontrolą wewnętrzną ze strony sądów państw członkowskich lub sądów unijnych. TS wskazał także na wyłączność swojej kompetencji co do orzekania o nieważności unijnego aktu prawnego, co stanowi jedną z cech porządku prawnego Unii. Z tego względu ETPC nie może orzekać o zgodności unijnego aktu prawnego z konwencją, zanim kwestii tej prawomocnie nie rozstrzygnie TS.

W komunikacie prezesów obu trybunałów (TS i ETPC) ${ }^{68}$ ze stycznia 2011 roku wskazano, że Trybunał wielokrotnie podkreślał, iż kontrolę przez TS ważności aktów unijnych w świetle praw podstawowych należy uważać za wyraz gwarancji konstytucyjnej, wynikającej z traktatów jako tworzących autonomiczny system prawny, którego umowa międzynarodowa nie może naruszać. Dlatego konieczne jest zagwarantowanie, aby w każdym przypadku wątpliwości co do zgodności z konwencją aktu prawa pochodnego zgodność tę mógł pierwotnie ocenić TS ${ }^{69}$. Należy w tym aspekcie rozróżnić sytuacje, gdy skargi do ETPC będą dotyczyć bezpośrednio aktów UE oraz gdy będą dotyczyć działań państw wprowadzających lub wykonujących te akty. W tym pierwszym przypadku warunek wyczerpania środków prawnych będzie wymagał skierowania sprawy do TS według zasad prawa UE, stąd zagwarantowane są uprzednia kontrola TS i respekt dla warunku subsydiarności ochrony ETPC. $\mathrm{W}$ drugim przypadku skarżący musi wykorzystać drogę prawa krajowego, w ramach której sąd może, a czasem musi wystąpić do TS z pytaniem prejudycjalnym. Jeśli tego nie zrobi, TS zostanie pozbawiony możliwości uprzedniego zbadania zgodności danego aktu z prawami podstawowymi. Jednak procedura prejudycjalna nie może być traktowana jako obowiązkowa w zakresie wyczerpania drogi prawnej, bo

\footnotetext{
${ }^{66}$ N. Półtorak, op.cit., s. 8. Zob. też ciekawie: T. Lock, EU Accession to the ECHR: Consequences for the European Court of Justice, Paper for EUSA Conference 2011 [materiał w posiadaniu autorki].

67 Zob. Dokument roboczy Trybunału Sprawiedliwości Unii Europejskiej dotyczący niektórych aspektów przystąpienia Unii Europejskiej do europejskiej konwencji o ochronie praw człowieka i podstawowych wolności, Luksemburg, 5 maja 2010.

${ }_{68}$ Zob. Joint communication from Presidents Costa and Skouris, Strasbourg and Luxembourg, 24 January 2011.

${ }^{69}$ N. Półtorak, op.cit., s. 8. Zob. też J.P. Jacqué, op.cit., s. 996.
} 
nie zależy ona od strony. Toteż należy wprowadzić specjalną procedurę, która da możliwość TS przeprowadzenia kontroli wewnętrznej, zanim ETPC przeprowadzi kontrolę zewnętrzną. Nie sprecyzowano jednak, o jaką procedurę może chodzić. Prezesi wskazali jedynie na to, że dla zapobieżenia przewlekaniu postępowania przed ETPC Trybunał mógłby zastosować postępowanie przyspieszone.

Rozwiązania przyjęte w projekcie umowy akcesyjnej w zasadzie uwzględniają formułę, którą zaproponowali prezesi obu trybunałów. W art. 3 ust. 6 projektu umowy akcesyjnej stwierdza się, iż „o ile w postępowaniach, w których współpozwanym jest Unia Europejska, Trybunał Sprawiedliwości Unii Europejskiej nie ocenił jeszcze zgodności z prawami zagwarantowanymi w Konwencji postanowienia prawa Unii Europejskiej wskazanego w ust. 2, zapewnia się Trybunałowi Sprawiedliwości Unii Europejskiej odpowiedni czas na dokonanie takiej oceny, a następnie stronom na zgłoszenie uwag. Unia Europejska zapewnia, że ocena taka jest przeprowadzana sprawnie, tak aby postępowanie przed Trybunałem nie uległo niepotrzebnej zwłoce. Ustęp niniejszy nie ma wpływu na kompetencje Trybunału”.

Uprzednie zaangażowanie TS niejako sankcjonuje więc obowiązującą w stosunku do państw-stron zasadę subsydiarności postępowań przed ETPC i przypomina poniekąd zasadę wyczerpania wszystkich środków przewidzianych prawem wewnętrznym przed wniesieniem skargi do ETPC. Niedopracowana pozostaje jednak kwestia uszczegółowienia procedury przed TS, jego stron i uprawnień, a także dookreślenia terminów procesowych.

To, że projekt umowy akcesyjnej nie odnosi się szczegółowo do takiej procedury, nie zaskakuje. Przeprowadzenie kontroli prawa unijnego co do zgodności z prawami podstawowymi jest bowiem przede wszystkim sprawą samej Unii. Problem zagwarantowania TS możliwości dokonania oceny prawa unijnego w sytuacji, gdy pojawi się zarzut naruszenia konwencji (a nie została wykorzystana droga pytania prejudycjalnego), powinien być podjęty w prawie unijnym, leży to bowiem przede wszystkim w interesie prawa unijnego ${ }^{70}$. Być może niezbędne stanie się wyodrębnienie nowej procedury względnie uzupełnienie procedury prejudycjalnej, choć wówczas konieczne byłoby chyba dokonanie zmiany w postanowieniach odpowiednich artykułów TFUE, a więc sięgnięcie do traktatu rewizyjnego ${ }^{71}$.

Wśród postanowień projektu umowy akcesyjnej znajdują się również kwestie związane z reprezentacją UE w organach konwencji. Dotyczy to w szczególności obecności sędziego UE w ETPC, zakresu reprezentacji UE w Komitecie Ministrów Rady Europy oraz w Zgromadzeniu Parlamentarnym Rady Europy.

\footnotetext{
70 L. Garlicki, Przystapienie UE... , op.cit., s. 18.

${ }^{71}$ J. Barcz, Traktat z Lizbony..., op.cit., s. 362.
} 
Projekt umowy akcesyjnej nie odnosi się w szczególny sposób do procedury wyboru sędziego, który będzie reprezentował Unię w ETPC, do jego statusu i zakresu obowiązków. Nie było to konieczne, bowiem w tym zakresie obowiązują Unię odpowiednie postanowienia EKPCz, tak jak każdą pozostałą stronę konwencji. Zgodnie $\mathrm{z}$ art. 20 Europejskiej konwencji... UE będzie reprezentował w ETPC jeden sędzia. W stosunku do tego sędziego obowiązują wymogi określone w art. 22 Europejskiej konwencji... oraz reguły dotyczące kadencji i odwołania określone w art. 23 Europejskiej konwencji... ${ }^{72}$. Stosownie do postanowień art. 22 Europejskiej konwencji... sędzia proponowany przez UE będzie wybierany przez Zgromadzenie Parlamentarne Rady Europy, większością głosów, spośród trzech kandydatów przedłożonych przez UE. Artykuł 6 projektu umowy akcesyjnej uzupełnia powyższe postanowienia, zapewniając delegacji PE prawo udziału w Zgromadzeniu Parlamentarnym Rady Europy i głosowania wówczas, gdy wybierani są - na podstawie art. 22 Europejskiej konwencji - sędziowie ETPC (ust. 1). Delegacja Parlamentu Europejskiego ma liczyć tylu członków, ilu liczy delegacja państwa mającego najmocniejszą reprezentację w Zgromadzeniu Parlamentarnym Rady Europy. Stosownie do art. 26 Statutu Rady Europy najwyższą liczbę przedstawicieli w Zgromadzeniu Parlamentarnym (po 18) mają Francja, Niemcy, Rosja, Włochy i Zjednoczone Królestwo. Tylu też przedstawicieli będzie liczyła delegacja Parlamentu Europejskiego.

Szczegółowe warunki udziału delegacji PE w stosownych posiedzeniach Zgromadzenia Parlamentarnego Rady Europy mają być uregulowane przez Zgromadzenie „we współpracy” z Parlamentem Europejskim (por. art. 6 ust. 2 projektu umowy akcesyjnej). Takie uzgodnienia między obu instytucjami zostały podjęte podczas trwania negocjacji nad projektem umowy akcesyjnej i znajdą wyraz w regulaminie wewnętrznym Zgromadzenia Parlamentarnego. Natomiast w regulaminie wewnętrznym Parlamentu Europejskiego będzie uregulowana procedura wyłaniania delegacji PE, która będzie uczestniczyć w stosownych posiedzeniach Zgromadzenia Parlamentarnego.

Zatem zgodnie z postanowieniami projektu umowy akcesyjnej Parlament Europejskie nie będzie miał swoich stałych przedstawicieli w Zgromadzeniu Parlamentarnym, ani nawet nie będzie w nim stale reprezentowany. Udział PE w pracach Zgromadzenia Parlamentarnego ograniczy się wyłącznie do posiedzeń związanych $\mathrm{z}$ wyborem sędziów do ETPC. Ponadto liczba delegatów Parlamentu Europejskiego (18 osób) będzie stanowić znaczną mniejszość Zgromadzenia Parlamentarnego. Ich interesy niekoniecznie muszą być zbieżne $\mathrm{z}$ interesami poszczególnych państw, ani nawet nie muszą być wewnętrznie zgodne. To w efekcie może powodować, że ich wpływ na wybór sędziów będzie ograniczony.

72 Ibidem, s. 362. 
W odniesieniu do konwencji ważne funkcje wykonuje również Komitet Ministrów Rady Europy. Komitet Ministrów jest jednym z zasadniczych organów Rady Europy, w którym reprezentowani są wszyscy jej członkowie - każde państwo ma jednego przedstawiciela, któremu przysługuje jeden głos (por. art. 14 Statutu Rady Europy). W szczególności Komitet Ministrów „czuwa” na wykonaniem wyroków ETPC (por. art. 46 Europejskiej konwencji...), sprawuje nadzór nad wykonaniem warunków porozumienia polubownego zawartego w toku postępowania przed ETPC (por. art. 39 ust. 4 Europejskiej konwencji...), może zwracać się do ETPC o wydanie opinii doradczej w kwestiach prawnych dotyczących wykładni konwencji i jej protokołów (por. art. 47 Europejskiej konwencji...) oraz decyduje - na wniosek Zgromadzenia Plenarnego ETPC - o zmniejszeniu liczby sędziów zasiadających w izbach Trybunału (por. art. 26 ust. 2 Europejskiej konwencji...).

$\mathrm{Z}$ tego względu zapewnienie udziału przedstawiciela UE w Komitecie Ministrów wydaje się niezbędne. Kwestię tę reguluje art. 7 ust. 1 projektu umowy akcesyjnej, stosownie do którego przedstawiciel UE uczestniczy w Komitecie Ministrów w zakresie, w jakim ten komitet podejmuje decyzje w sprawach:

- objętych wspomnianymi wyżej artykułami 26 ust. 2, 39 ust. 4, 46 ust. 2 do 5 lub art. 47 Europejskiej konwencji... ,

- dotyczących przyjęcia protokołów do konwencji,

- dotyczących przyjęcia lub wykonania każdego innego środka lub dokumentu skierowanego do ETPC lub do wszystkich stron konwencji, względnie dotyczącego wykonywania przez Komitet Ministrów lub Zgromadzenie Parlamentarne funkcji na podstawie konwencji ${ }^{73}$.

Projekt umowy akcesyjnej nie rozstrzyga o tym, przedstawiciel jakiej instytucji względnie organu unijnego będzie reprezentował UE w Komitecie Ministrów. Statut Rady Europy w art. 14 stwierdza, że przedstawicielami członków Rady Europy w Komitecie Ministrów są ministrowie spraw zagranicznych, względnie - gdy nie może on być obecny - wyznaczony zastępca („którym, jeśli to możliwe, będzie członek jego rządu"). Ponieważ - jak wspomniano - problemu tego nie rozstrzygnął projekt umowy akcesyjnej, jest on sprawą wewnętrznej decyzji Unii Europejskiej.

Najistotniejszym problemem, związanym z udziałem przedstawiciela UE w Komitecie Ministrów przy decydowaniu w powyższych sprawach, zwłaszcza związanych z nadzorowaniem przez Komitet Ministrów wykonania wyroków ETPC (art. 46 Europejskiej konwencji...) i warunków polubownego załatwienia sprawy (art. 39 ust. 4 Europejskiej konwencji...), było uzgodnienie formuły podejmowania decyzji przez Komitet Ministrów. Trzeba bowiem zważyć, że państwa członkowskie

73 Ibidem, s. 364. 
UE wraz z przedstawicielem Unii w Komitecie Ministrów stanowią większość (28 na łączną liczbę 48 członków), a w sprawach objętych kompetencją UE będą głosowali w sposób skoordynowany. Należało więc tak ustalić formuły podejmowania decyzji, aby zapewnić „efektywność wykonywania przez Komitet Ministrów jego funkcji nadzorczej określonej w artykułach 39 i 46 Konwencji" (por. art. 7 ust. 2 projektu umowy akcesyjnej) $)^{74}$.

Problem ten reguluje projekt umowy akcesyjnej. W art. 7 ust. 2 lit. a projektu umowy akcesyjnej odniesiono się do podejmowania przez Komitet Ministrów decyzji w ramach nadzoru wykonania wyroków lub warunków polubownego załatwienia sprawy, będących następstwem spraw, w których pozwaną była sama Unia Europejska lub w których była współpozwaną. W takim przypadku od regulacji unijnych zależy, czy przedstawiciel Unii Europejskiej oraz przedstawiciele jej państw członkowskich wyrażać będą w głosowaniu stanowisko w sposób skoordynowany. Postanowienia art. 7 ust. 2 lit. a projektu umowy akcesyjnej podkreślają, że należy w taki sposób dostosować Zasady Komitetu Ministrów w sprawie nadzorowania wykonania wyroków oraz warunków polubownego załatwienia spraw ${ }^{75}$, aby „zapewnić, że Komitet Ministrów będzie efektywnie wykonywał swoje funkcje w powyższych okolicznościach".

Dlatego też sprecyzowano formuły głosowania w przypadkach nadzorowania przez Komitet Ministrów wyroków względnie warunków polubownego załatwiania spraw będących następstwem współpozwania (por. art. 7 ust. 2 lit a. projektu umowy akcesyjnej). Zasady KM... uzupełniono nową Zasadą 18, stosownie do której w przypadku, gdy Komitet Ministrów nadzoruje wykonanie zobowiązań albo przez samą Unię Europejską, albo przez Unię Europejską oraz jedno lub więcej państw członkowskich UE, ustalono generalną zasadę, iż decyzję Komitetu Ministrów uważa się za podjętą, jeśli na jej rzecz wypowiedziała się zwykła większość jego członków reprezentujących te wysokie układające się strony, które nie są członkami UE. Od tej generalnej zasady są przewidziane dwa istotne wyjątki. Po pierwsze, w przypadku decydowania przez Komitet Ministrów w kwestii zwrócenia się z wnioskiem do ETPC o opinię doradczą (Zasada 10) oraz sprawach o naruszenie obowiązku wykonania wyroku (Zasada 11) decyzję Komitetu Ministrów uważa się za podjętą, jeśli za jej podjęciem wypowiedziało się dwie trzecie jego członków reprezentujących te układające się strony, które nie są członkami UE (Zasada 18). Po drugie, w przypadku decydowania przez Komitet w sprawie final resolutions (Zasada 17) sprecyzowano formułę głosowania $\mathrm{w}$ ten sposób, iż dla podjęcia decyzji przez

\footnotetext{
74 Ibidem, s. 365 .

75 Zob. Rules of the Committee of Ministers for the supervision of the execution of judgments and the terms of friendly settlements, adopted by Committee of Ministers at the 964 th meeting of the Deputies, on 10 May 2006.
} 
Komitet Ministrów wymagane jest nie tylko spełnienie warunków określonych w art. 20 lit. d Statutu Rady Europy. Dla podjęcia decyzji wymagana jest bowiem nie tylko „większość dwóch trzecich oddanych głosów i większość przedstawicieli uprawnionych do zasiadania w Komitecie", lecz również, aby na jej rzecz oddano zwykłą większość oddanych głosów członków reprezentujących te wysokie układające się strony, które nie są członkami UE (Zasada 18) ${ }^{76}$.

Kolejne postanowienia art. 7 ust. 2 projektu umowy akcesyjnej (litery b i c) mają wytyczyć granice, określające zakres oddziaływania prawa UE w stosunku do działań Unii oraz jej państw członkowskich w odniesieniu do nadzorowania przez Komitet Ministrów wykonania obowiązków wynikających z konwencji przez państwa członkowskie UE oraz strony konwencji niebędące państwami członkowskimi UE. Pierwszy z regulowanych przypadków (por. art. 7 ust. 2 lit. b projektu umowy akcesyjnej) odnosi się do nadzorowania przez Komitet Ministrów wykonania obowiązków wynikających z konwencji przez państwo członkowskie UE. Na mocy traktatów stanowiących podstawę Unii, jeśli nie ma ona w odpowiednich dziedzinach kompetencji to wykluczone jest zajmowanie przez Unię stanowiska oraz prawo głosowania. W takich przypadkach traktaty stanowiące podstawę UE nie zobowiązują państw członkowskich UE do zajmowania stanowiska i głosowania w sposób skoordynowany. Natomiast w przypadku (por. art. 7 ust. 2 lit. c projektu umowy akcesyjnej), gdy Komitet Ministrów nadzoruje wykonania obowiązków wynikających z konwencji przez państwo niebędące członkiem UE, wówczas traktaty stanowiące podstawę UE nie zobowiązują państw członkowskich Unii do zajmowania stanowiska lub głosowania w sposób skoordynowany. Nawet jeżeli Unia Europejska zajmie $\mathrm{w}$ danej sprawie stanowisko lub skorzysta $\mathrm{z}$ prawa do głosowania ${ }^{77}$.

W kontekście analizy kwestii instytucjonalnych warto również wspomnieć, że projekt umowy akcesyjnej zobowiązuje UE do respektowania postanowień umów międzynarodowych związanych bezpośrednio z funkcjonowaniem systemu konwencji (por. art. 9 projektu umowy akcesyjnej ${ }^{78}$. Umowy te przewidują przywileje i immunitety samej Rady Europy, przedstawicieli państw w Komitecie Ministrów

\footnotetext{
76 Należy zauważyć, że powyższe formuły głosowania określone są jedynie w zasadach przyjmowanych przez sam Komitet Ministrów, a nie w umowie akcesyjnej czy konwencji. W przyszłości mogą być one zatem modyfikowane przez Komitet Ministrów, bez konieczności zmiany umowy akcesyjnej czy też konwencji.

77 J. Barcz, Traktat z Lizbony..., op.cit., s. 367. Zob. też X. Groussot, T. Lock, L. Pech, EU Accession to the European Convention on Human Rights: a Legal Assessment of the Draft Accession Agreement of 14th October 2011, „European Issues” 2011, Nr 218, s. 8-9.

78 Chodzi o: Europejskie porozumienie dotyczące osób uczestniczących w postępowaniach przed Europejskim Trybunałem Praw Człowieka z 5 marca 1996 roku; Ogólne porozumienie o przywilejach i immunitetach Rady Europy z 2 września 1949 roku oraz dołączony do niego Protokół z 6 listopada 1952 roku i Szósty Protokół z 5 marca 1996 roku.
} 
i Komitecie Delegatów Ministrów, deputowanych zasiadających w Zgromadzeniu Parlamentarnym i ich zastępców, przedstawicieli państw przy Radzie Europy, funkcjonariuszy Rady Europy, a także sędziów i ich rodzin oraz funkcjonariuszy ETPC ${ }^{79}$.

Jako strona konwencji UE będzie także zobowiązana wnosić wkład finansowy na poczet kosztów związanych z działaniem systemu kontrolnego konwencji. Do tej sprawy odnosi się art. 8 projektu umowy akcesyjnej. Postanawia on, że UE będzie płaciła roczną składkę dodatkową w stosunku do tej, która jest płacona przez poszczególne państwa członkowskie. Przez koszty działania konwencji rozumie się tutaj koszty działania ETPC, kontroli wykonywania wyroków ETPC, a także koszty głównych organów Rady Europy w zakresie, w jakim konwencja powierza im wykonywanie różnych funkcji, wreszcie koszty administracyjne w wysokości 15\% ogólnych kosztów administracyjnych.

\section{Wnioski}

Ustanowienie na mocy Traktatu z Lizbony podstawy prawnej dla przystąpienia Unii Europejskiej do Europejskiej konwencji o ochronie praw człowieka i podstawowych wolności i jednocześnie zobowiązanie Unii do takiego przystąpienie (art. 6 ust. 2 TUE) jest ważnym elementem (obok nadania KPP charakteru prawnego oraz utrzymania kompetencji TS do kreowania praw podstawowych jako zasad ogólnych prawa unijnego) generalnego umocnienia ochrony praw podstawowych jednostki w ramach Unii Europejskiej.

Trudno obecnie przewidzieć, jakie będzie dalsze tempo prac nad umową akcesyjną i jakie będą jej ostateczne postanowienia. Punktem wyjścia obecnych negocjacji jest jednak polityczna decyzja państw członkowskich UE, wyrażona w postanowieniach Traktatu z Lizbony i w sposób wyraźny nakazująca przystąpienie UE do konwencji. Oznacza to, że państwa członkowskie UE uznały, że dotychczasowy stan prawny, oparty na niezbyt jasnej równoległości i odrębności systemu prawnego UE i konwencji, nie zasługuje na kontynuację i powinien ulec zmianie. Skoro zaś zmiana ta polega na wejściu UE do mechanizmów konwencji, to kryje ona w sobie rozstrzygnięcie kierunkowe, że UE decyduje się na uznanie takich gwarancji praw człowieka, jakie zostały ukształtowane w systemie konwencji ${ }^{80}$.

\footnotetext{
${ }^{79}$ C. Mik, op.cit., s. 66.

${ }^{80}$ L. Garlicki, Przystapienie UE..., op.cit., s. 16.
} 
Akcesja Unii Europejskiej do konwencji jest zabiegiem skomplikowanym. Wymaga ona dostosowań zarówno po stronie konwencji, jak i po stronie Unii oraz ustalenia zasad współdziałania obu systemów, tak aby ochrona praw podstawowych została umocniono zarówno w skali zakresu obowiązywania konwencji, jak i w ramach Unii Europejskiej. Akcesja przyczyni się do umocnienia europejskiego systemu ochrony praw człowieka. Powinna ona prowadzić przede wszystkim do eliminacji obecnej konkurencyjności obu porządków ochrony praw i związanych z tym zagrożeń. Wynikają one przede wszystkim z nakładania się kompetencji orzeczniczych ETPC i TS, w szczególności z przyznania TS roli sądu rozstrzygającego o zgodności prawa UE i działań UE, a pośrednio także prawa krajowego z prawami zawartymi w konwencji, a obecnie też w KPP. Rozbieżności te dotychczas zdarzały się rzadko. Dotyczyły jednak ważnych zagadnieńn ${ }^{81}$.

Dopóki UE nie przystąpi do konwencji, jednostki nie będą miały możliwości wnoszenia skarg przeciwko instytucjom Unii bezpośrednio przed ETPC. Unia Europejska pozostaje bowiem jedynym systemem prawnym, w którym akty prawne nie są przedmiotem zewnętrznej kontroli tego sądu. Akcesja wypełni tę lukę w ochronie praw podstawowych UE i jej instytucje będą przedmiotem takiej samej zewnętrznej kontroli, jak akty prawne jej państw członkowskich. Zatem akcesja umocni oba sądy.

Przystąpienie UE do konwencji daje wyraźny sygnał, że UE jest gotowa zaakceptować m.in. zewnętrzną kontrolę jej systemu sądowego. Wszystkie państwa członkowskie UE ratyfikowały konwencję i tym samym stały się podmiotami polegającymi kontroli ETPC. Akcesja powinna być korzystna dla zapewnienia spójnej ochrony praw podstawowych w całej Europie, nie tylko w ramach UE. Poprzez akcesję TS byłby związany praktyką sądową ETPC.

Związanie się przez UE konwencją pokazuje także, że Unia Europejska nie stoi „ponad prawem”, gdy chodzi o ochronę praw podstawowych jednostki. Instytucje unijne poddane zostaną bowiem niezależnej kontroli zewnętrznej. Oznacza to tym samym zmianę sposobu badania prawa UE przez ETPC. Taka kontrola będzie bowiem kontrolą bezpośrednią, a nie jak to ma miejsce obecnie pośrednią poprzez akty państw członkowskich UE.

81 N. Półtorak, op.cit., s. 6. Chodzi np. o zakres prawa do poszanowania życia prywatnego (art. 8 Europejskiej konwencji...) w odniesieniu do możliwości przeszukania mieszkania, w którym prowadzona jest działalność gospodarcza. TS odmiennie niż ETPC uznał, że takie mieszkanie nie jest objęte ochroną Zob. wyrok TS z 21 września 1989 r. w sprawach połączonych 46/87 i 227/88 Hoechst przeciwko Komisji, Zb. Orz. 1989, s. 2859 oraz wyrok ETPC z 16 grudnia 1992 r. w sprawie Niemietz przeciwko Niemcy, skarga nr 13710/88 oraz wyrok ETPC z 16 kwietnia 2002 r. w sprawie Colas Société Colas Est przeciwko Francji, skarga nr 37971/97. 


\section{EU accession to The European Convention on Human Rights}

The aim of this text is to analyze the regulations adopted in the Lisbon Treaty regarding the EU accession to the European Convention on Human Rights. The Treaty made the accession obligatory. Shortly after the Treaty was ratified the EU opened the negotiations with the Council of Europe on accession treaty. The project of accession treaty was drafted in July 2011 and was the starting point for next round of negotiations. This text lists the legal basis for the EU accession to the Convention. Detailed problems were presented in the formal aspect (form, scope and procedure of accession), institutional aspect (the question of EU representation in the Convention bodies) and material aspect (the question of EU liabilities resulting from the Convention in the context of its work).

\section{L'adhésion de l'Union européenne à la Convention européenne pour la protection des droits de l'homme et des libertés fondamentales}

Le but de cette étude est d'analyser les solutions juridiques adoptées dans le traité de Lisbonne en ce qui concerne la question de l'adhésion de l'UE à la Convention européenne pour la protection des droits de l'homme et des libertés fondamentales. Après l'entrée en vigueur du traité de Lisbonne, les négociations entre l'UE et le Conseil de l'Europe sur le contrat d'adhésion ont commencé. Le projet du contrat a été créé en juillet 2011 et ensuite, il a fait l'objet de nouvelles négociations. Cet article montre la base juridique et les principes qui déterminent l'adhésion à la Convention. Lauteur fait référence aux aspects formels (la forme et la portée de l'adhésion), institutionnels (la question de la représentation de l'UE dans les organes de la Convention) et matériels (le problème des engagements de l'UE dans le cadre de la Convention dans le contexte de son fonctionnement). 